\title{
Raman and XRF classification of Asian and European glass beads recovered at Mutamba, a southern African Middle Iron Age site
}

\author{
Farahnaz Koleini $^{\mathrm{a}^{*}}$, Philippe Colomban ${ }^{\mathrm{b}}$, Alexander Antonites ${ }^{\mathrm{a}}$, Innocent Pikirayi ${ }^{\mathrm{a}}$ \\ ${ }^{\mathrm{a}}$ Department of Anthropology and Archaeology, University of Pretoria, Hatfield 0028, South Africa. \\ ${ }^{\mathrm{b}}$ Sorbonne Universités, UPMC Univ Paris 06, UMR 8233, CNRS, MONARIS, F-75005, Paris, France.
}

\section{Abstract}

Twenty-eight representative beads found at the thirteenth-fourteenth century AD site of Mutamba in southern Africa were classified morphologically and then analysed with pXRF. Eighteen beads were selected from four identified series of K2-IP, EC-IP, Mapungubwe Oblate and European for Raman spectroscopy. The results show corrosion has a great effect on the composition and nanostructure of Mapungubwe series with lixiviation of alkalis. In corroded K2-IP beads elevated amounts of potassium recorded on the surface layer compared to less corroded IP beads. Despite these changes pXRF and Raman spectroscopy were successful in discriminating of the bead series by considering the concentration of trace elements ( $\mathrm{Zr}, \mathrm{U})$, detected pigments (lead tin yellow (II), red lead), opacifiers $\left(\mathrm{SnO}_{2}\right.$, calcium antimoniate) and colorants $(\mathrm{Fe}, \mathrm{Cu}, \mathrm{Co})$ and their concentrations in the beads.

Key words: Glass trade beads; Indian Ocean; southern Africa, corrosion; Raman spectroscopy; pXRF

\section{Introduction}

Glass beads occur in southern African archaeological contexts dating from the second half of the first millennium AD. The beads attest to international trade networks connecting southern Africa with eastern Africa and southern Asia (Abraham, 2016; Beaujard, 2012; Francis, 1990; Francis, 2002; Robertshaw et al. 2010). From the early second millennium AD, early state-level societies in southern Africa based at Mapungubwe in the Shashe-Limpopo confluence, and at Great Zimbabwe in south-central Zimbabwe, traded large quantities of these items. Actually, the number of studied sites is rather limited when we consider the extent of the geographical area concerned. One of these sites, Mutamba, is a settlement

\footnotetext{
* Corresponding author. E-mail address: farakoleini@gmail.com
} 
1 located on the northern slopes of Soutpansberg mountain range, on the margin of Shashe-

2 Limpopo confluence in the north of South Africa (Fig. 1). It falls within the period known as 3 the southern African Middle Iron Age (AD 900-1300 [cf. Huffman, 2007]), and dates to the

4 thirteenth and early fourteenth centuries AD. This period is associated with social and

5 political developments in the Shashe-Limpopo confluence zone that gave rise to the

6 Mapungubwe State during the early thirteenth century (Antonites, 2014). This process sees a

7 significant increase in long distance trade involving the Indian Ocean, characterized by

8 exports of gold and animal products such as ivory and skins, and imports in the form of Asian 9 ceramics and glass beads (Fouché, 1937; Huffman, 2000, 2007; Meyer, 2000).

10

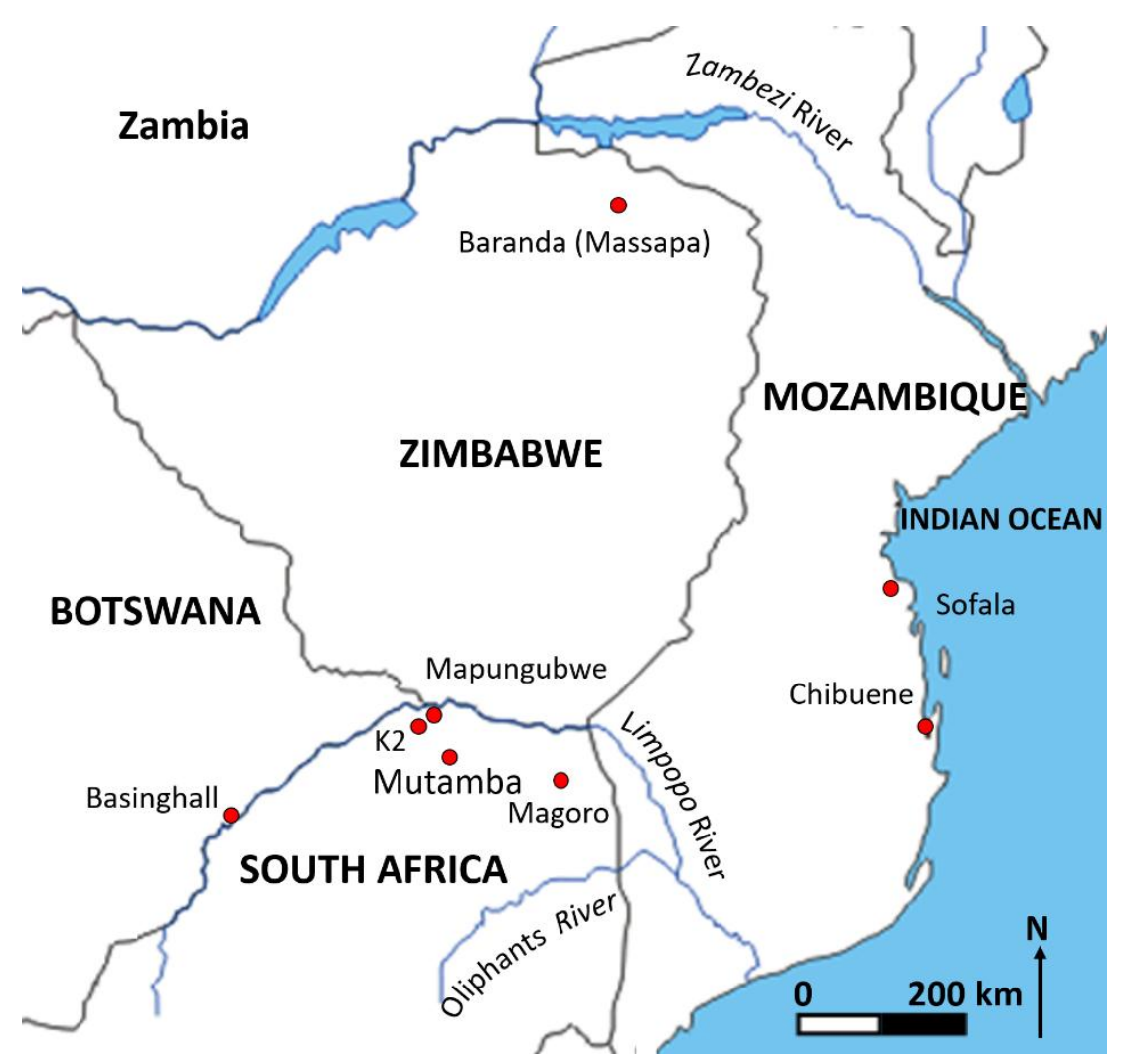

Figure 1: Map showing Mutamba and other archaeological sites mentioned in the text.

11 Mutamba was excavated in 1988 (Loubser, 1988) and 2010-11 (Antonites, 2012). While no 12 beads were found in the initial excavations by Loubser (limited to a $3 \mathrm{~m} \times 3 \mathrm{~m}$ trench), later excavations (13 excavation units covering $48 \mathrm{~m}^{2}$ in total) recovered 348 glass beads

14 (Antonites, 2014). In addition to the glass beads, links with the Shashe-Limpopo Confluence are suggested by trade objects such as cowrie shell and metals such as gold, copper and iron objects as well as pottery. 
1 Traded glass beads have been found in southern African archaeological context since the 2 seventh century AD (Denbow et al. 2015; Wood et al. 2012). First, Asian/African (seventh-

3 fifteenth century) and later European traders (fifteenth century onward) exchanged glass

4 beads for precious commodities such as gold and ivory (Beaujard, 2012, 2009). The variety

5 of the beads in morphology and composition shows different production centres and glass

6 sources. The composition of these glass beads closely resemble the glass produced in the

7 eastern side of the Euphrates River (7th-10th centuries AD), south and south-east Asia (10th-

8 17th centuries AD) (Robertshaw et al. 2010; Wood et al. 2012) and Europe (17th century

9 onwards) (Koleini et al. 2016a; Tournié et al. 2012). In Asia, socio-political changes in centres of production since the mid-10th century resulted in shifts in trading routes from the Middle East to South and Southeast Asia towards southern Africa. Thus can be documented through morphology and composition of the beads (Wood, 2011). These criteria were used to establish old-trade connections and chronology of sites by archaeologists (e.g. Calabrese, 2007; Denbow et al. 2015; Schofield, 1938).

The beads from Mutamba were morphologically classified by Antonites (2014) based on the temporal sensitive classification system provided by Wood (2000, 2011). Wood's classification system is the common and accepted method in field archaeology of southern Africa. Wood (2011) identified seven series of glass beads imported into southern Africa between the seventh and the sixteenth centuries AD (Table S1). The similarities and differences in the chemical composition of a selection of representative beads of each series were examined by Robertshaw et al. (2010) using laser-ablation inductively coupled plasma mass spectrometry (LA-ICP-MS). The method is very accurate for measuring concentration of elements, including light ones in the (small) probed volume. However, it has been demonstrated that many beads are heterogeneous (Koleini et al., 2016a, 2016b), as many coloured/opaque glass objects (Neri et al., 2016) and thus techniques probing a larger volume of matter such as XRF instruments are interesting. Furthermore, current archaeological ethics promote the conservation and study of the artefacts close to their excavation sites. Portable XRF (pXRF) and Raman instruments have demonstrated potential for on-site analyses (Rougeulle et al., 2014; Simsek et al. 2014; Tournié et al., 2011) and their moderate cost and adaptability are more convenient for field archaeologists when compared to costly fixed instruments such as LA-ICP-MS.

The Near East, with its particular low aluminium plant ash glass (Chibuene and Zhizo series), and South Asia, with high aluminium soda glass (K2, East Coast and Khami series), are 
1 identified as two sources of the beads. The high aluminium plant ash glass of Mapungubwe oblates and Zimbabwe series were probably imported from South Asia but the exact source is not clear (Wood, 2011). The soda glass beads imported from South Asia via the Indian Ocean are categorized as Indo-Pacific (IP) series (Wood, 2011).

5 In this article, chemical structure and composition of a representative series of beads found at 6 Mutamba are examined by means of pXRF and Raman spectroscopy following the method 7 provided by Koleini et al. (2016b). In this method, the glass type is identified by Raman spectroscopy, a non-invasive technique already used for glass beads from K2 (AD 980-1200) and Mapungubwe (thirteenth century and possibly up to the mid-nineteenth century AD) in the middle Limpopo valley (Prinsloo and Colomban, 2008; Tournié et al. 2012). Three general types of glass namely, soda, soda/lime and lead were detected, in addition to some temporal marker pigments such as calcium antimoniate and lead arsenate which discriminated European beads (seventeenth-nineteenth century) from the earlier beads (seventh-seventeenth century). Portable XRF with support of Raman results easily differentiates subgroups in each type of glass by considering elemental concentration. There was no order of preference for using either Raman or pXRF for analysing the glass beads. Representative samples within each series were analysed with both instruments. Any anomaly observed in the results based on the use of one instrument required that the sample be analysed with the other instrument. In this study, we used pXRF first. According to Koleini et al. (2016b), K2IP and East Coast-IP (EC-IP) beads (soda type) have almost the same glass composition while Khami-IP (K-IP) (soda type) can be identified by their higher aluminium and calcium content.

All the mentioned soda types glass are close to glass composition of south and south east Asia reported by Dussubieux et al. (2010). Mapungubwe oblates (soda/lime) show higher magnesium and calcium content, though the uranium is lower than detection limit, which is higher in the IP series. XRF also distinguishes metallic ions used as colorants in glass matrix (Koleini et al. 2016b). This method was successfully used for identification of the southern African beads series dating from the tenth to the seventeenth century (Koleini et al. 2016b, Koleini et al. 2017) and European beads traded after the seventeenth century (Koleini et al. 2016a). As most glass beads are found in a corroded form in most archaeological contexts, we examined the potential of Raman and pXRF techniques in the identification of southern Africa glass beads series. 


\section{2. Materials and methods}

\subsection{XRF measurements}

3 A portable Thermo Scientific Niton XL3t GOLDD supplemented with a Niton XL3 portable

4 test stand were used. The beads were directly placed on $8 \mathrm{~mm}$ test window and measured

5 using mining $\mathrm{Cu} / \mathrm{Zn}$ modes. The instrument was adjusted to detect four elemental ranges of

6 main, low, high and light in 240 seconds. The limit of detection (LOD) of the elements was

7 calculated using a 2 sigma range. The instrument measures the concentration of elements

8 heavier than magnesium $(\mathrm{Mg})$ and reports the result in the form of element wt\% while the

9 concentration of undetected elements is calculated by the device to give a $100 \mathrm{wt} \%$ total

10 balance. For full details see Koleini et al. (2016b).

11 Peak overlap and chemical matrix effect could complicate quantitative measurements. For instance, the emission line overlap of lead (L $\alpha$ at $10.55 \mathrm{keV})$ and arsenic ( $\mathrm{K} \alpha$ at $10.54 \mathrm{keV})$ when both present in the matrix, raises the limit of detection of arsenic with increasing lead $(\mathrm{Pb})$ content. There is also an important limitation in the detection of low energy X-rays of light elements. Consequently, the concentration of elements lighter than magnesium is not measured and the detection limit of the light elements would be higher than the heavy elements. In contrast, the precision of the instrument is very good for most of the other elements (<5\%RSD) (Brand et al. 2014). For all these reasons the final result will be expressed in element wt $\%$ and not in converted oxide wt $\%$, since the later formulation requiring the concentrations of all main glass elements. To compare the results, the literature expressed in oxides wt $\%$ have been converted in element wt $\%$. Furthermore, some of the classified and analysed beads by Robertshaw et al. (2010) stored in the van Riet Lowe bead collection at the University of the Witwatersrand were also examined using pXRF. The results were compared with LA-ICP-MS data provided by Marilee Wood for some of the abovementioned beads. The XRF measurements (element wt\%) show trends comparable to data from Marilee Wood as well as the data available in Robershaw et al. (2010) for the glass former, stabilizer, and, some of the trace elements (Table S2).

\subsection{Raman measurement}

30 The Raman spectra were recorded with an HR Raman instrument (Horiba Jobin Yvon, 31 France) equipped with an $\mathrm{Ar}^{+}$ion Coherent laser (458nm line) and an optical microscope 32 (Olympus, Japan) making it possible to focus the laser beam on a selected area on the bead 
1 using a 50x long working distance objective. The analyzing spot diameter is about $10 \mu \mathrm{m}$ and

2 the illumination power at the sample is $\sim 2 \mathrm{~mW}$. A Labram Infinity spectrometer (Dilor,

3 France) equipped with a $633 \mathrm{~nm}$ He laser line was used on one of the black beads due to the spectroscopy failure with the lower wavelength laser line on the glass matrix (x50 lwd objective, $\sim 0.5 \mathrm{~mW}$ at the sample). Several spots on each bead were examined by Raman to get the spectra of glass matrix, pigments and opacifiers. The spectra baselines were subtracted in four points of $\sim 200,700,800$ and $1300 \mathrm{~cm}^{-1}$ to eliminate the effect of fluorescence followed by the method provided by Colomban (2003).

\subsection{Samples, morphology and series}

Twenty-eight representative drawn glass beads were selected from the Mutamba assemblage. The selection was based on the morphology and conditions of the beads, ranging from corroded to those seemingly non-corroded. The beads were cleaned with deionized water to remove contaminants and then dried up. According to Wood's (2011) classification, the Mutamba assemblage is broadly characterized by three series, namely K2-IP, EC-IP and Mapungubwe oblates. There are also two dark blue European beads in the assemblage. Regarding the method of fabrication and size of beads, only four wound beads were discovered at Mutamba while the rest are drawn and with the majority small and minute in size (diameter $<3.5 \mathrm{~mm})$. Only eight medium size beads $(>3.55-4.5 \mathrm{~mm})$ were identified. The majority of beads are oblate in shape $(64 \%)$ followed by cylinder $(30 \%)$ and tube $(6 \%)$. Black is the most prominent colour (65.3\%) followed by blue-green (17.2\%), brownish-red $(11.7 \%)$, green $(3.4 \%)$, yellow $(1.8 \%)$, and dark blue $(0.6 \%)$. Most of the beads are heavily corroded which made morphological classification difficult (Antonites, 2014).

\section{Results and discussion}

The beads selected from the Mutamba assemblage were analysed with pXRF (Table S3). The average concentration of twenty-four detected elements for different colours of Mutamba beads in each series is presented in Table 1. The result for Mapungubwe and K2-IP corroded beads (Map/Cor and K2/Cor) are separately included in Table 1 for comparison with the composition of un-corroded samples within the same series. The eighteen beads selected for Raman spectroscopy (Fig. 2) were based on composition and morphology. It means that from the beads with the same elemental composition and morphology, only one was selected. 


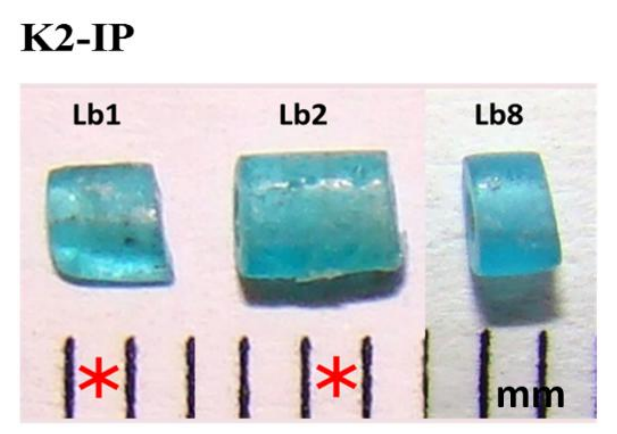

Map oblate
EC-IP

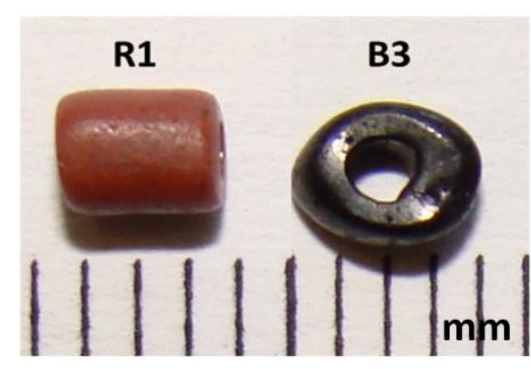

?

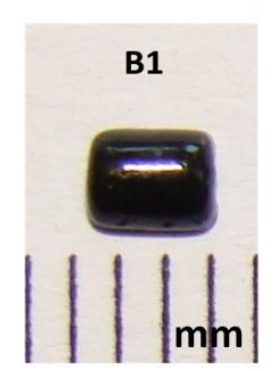

European
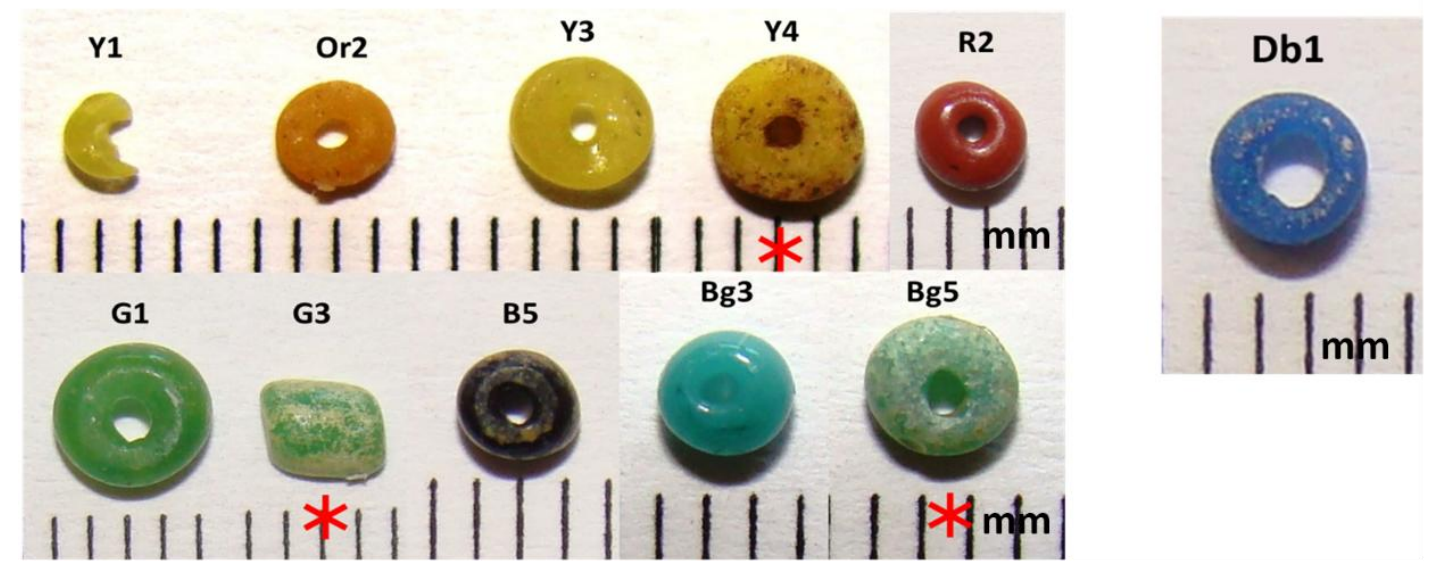

Figure 2: Morphological classification of representative beads found at Mutamba according Wood (2011). Lb: light blue, R: red, B: black, Y: yellow, Or: orange, G: green, Bg: blue green and Db: dark blue. $*$ shows corroded beads.

1 The Raman spectrum of every glass consists of two broad components of bending (415-

$\left.2570 \mathrm{~cm}^{-1}\right)$ and stretching $\left(700-1100 \mathrm{~cm}^{-1}\right)$ vibration of $\mathrm{Si}-\mathrm{O}$ bonds in the $\mathrm{SiO}_{4}$ structural unit of

3 glass network. The composition of glass and manufacturing procedure such as melting

4 temperature and annealing duration modify the glass nanostructure, and therefore on wavenumber position and intensity of peaks in the abovementioned bending and stretching components. The spectrum of glass matrix is used to identify glass chemical types by plotting wavenumber of the maximum intensity peaks in bending $\left(\delta_{\max } \mathrm{Si}-\mathrm{O}\right)$ and stretching components ( $\left.v_{\max } \mathrm{Si}-\mathrm{O}\right)$ (Colomban et al. 2003, Prinsloo et al. 2011; Tournié et al. 2012). The result for Mutamba glass beads are presented in Fig. 3. Two glass types of soda and soda/lime were identified based on the recorded spectra on glass matrices presented in Fig.4a.

11 Un-corroded K2 and EC-IP beads have been situated in the soda group while Mapungubwe

12 oblate beads fall in the soda/lime glass type, which is in accordance with XRF measurements.

13 A more comprehensive discussion on glass structures, compositions, pigments and colorants

14 of beads in each identified series is presented in the following section. 


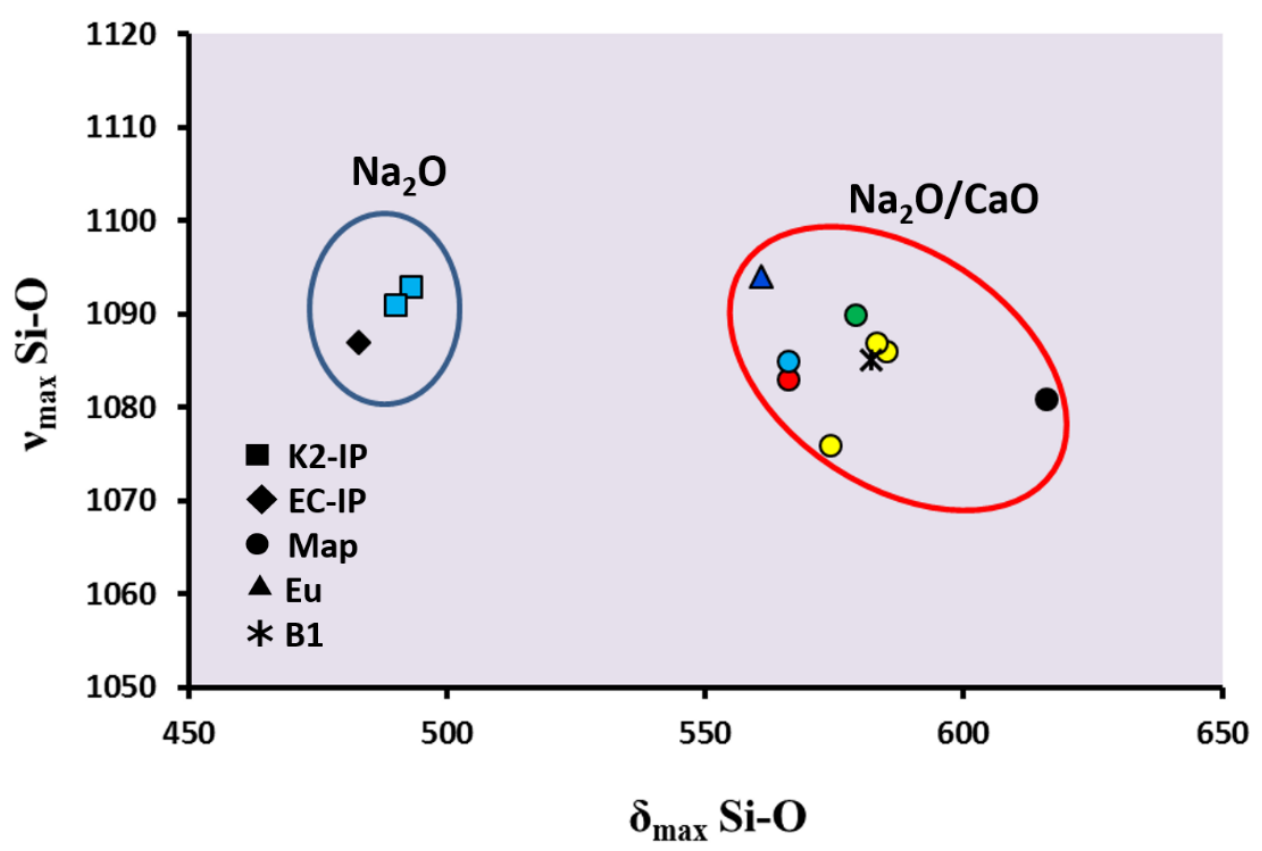

Figure 3: Plot of the maximum peaks intensity at bending versus stretching $\mathrm{SiO}_{4}$ bands. Colour fills show colour of the beads.
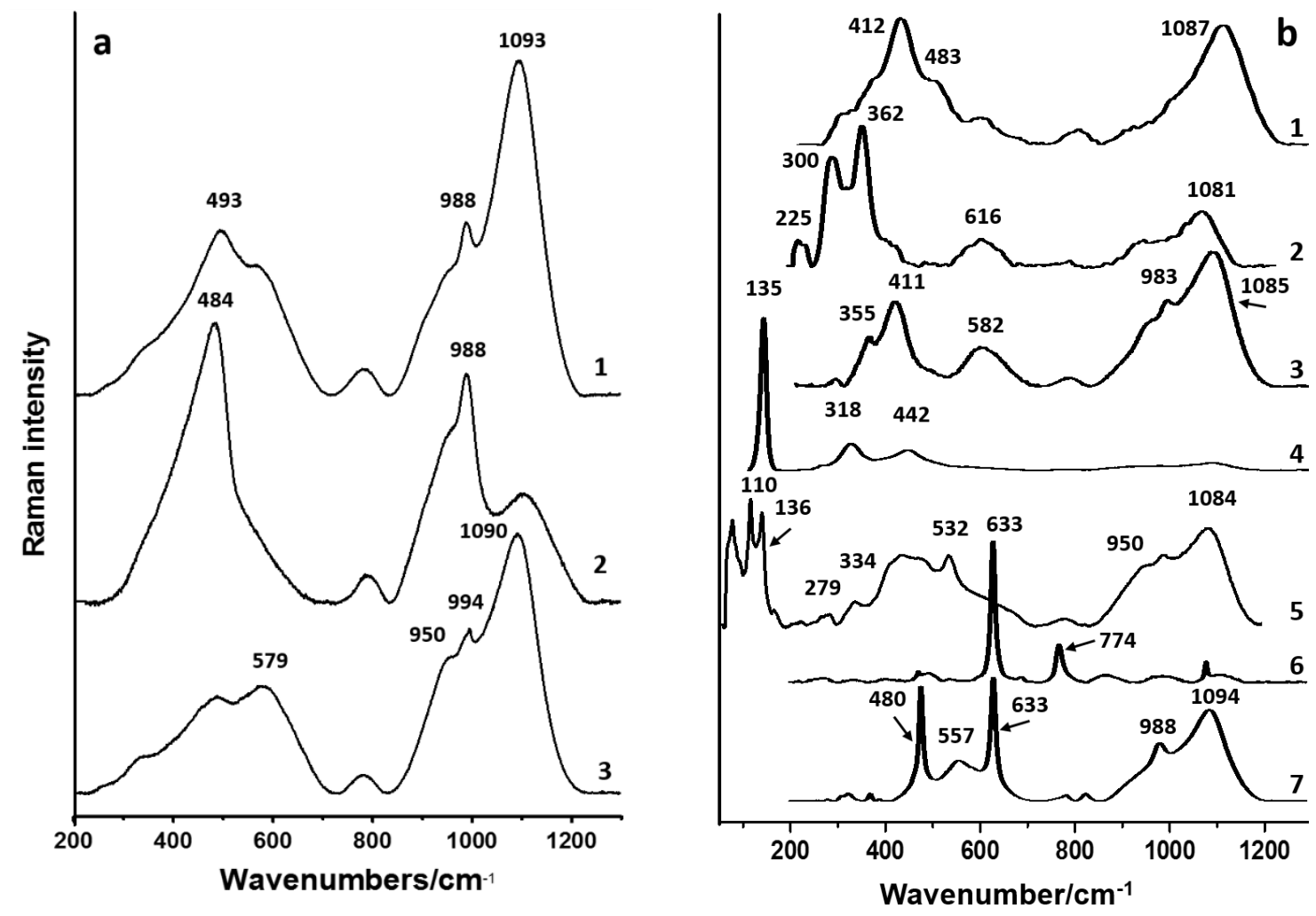

Figure 4: Representative Raman spectra of a) typical glass matrices of 1- K2-IP 2- Corroded K2-IP 3 Map Oblate. b) pigments: 1- Fe-S chromophore (amber) in EC-IP series 2- Fe-S chromophore in Map Oblate 3- Fe-S chromophore in (B1) 4- Lead tin yellow (II) 5- lead tin yellow (II) and red lead 6- Tin oxide 7- Calcium antimonite 
2 The K2-IP beads in this assemblage are tubular, transparent-translucent and brilliant

3 turquoise in colour (Fig. 2). XRF measurements detected high aluminium (8.28 wt \%) and

4 low calcium (2.02 wt\%) with magnesium lower than the detection limit of instrument that

5 shows the same trend in composition with mineral soda glass of IP series reported by

6 Robertshaw et al. (2010) and those recovered at Basinghal Farm, in Botswana (Fig. 5a, Table

7 1, Table S2). All the beads contain high uranium content ( $38 \pm 24 \mathrm{ppm}$ ) (Table 1). Lb8 with

$84.5 \mathrm{wt} \%$ potassium matches the K2-IP beads found elsewhere in southern Africa. Lb1 and

9 Lb2, Lb-Cor in Table 1, show a higher potassium (mean $7.82 \mathrm{wt} \%$ ) than Lb8 and the

10 maximum amount reported for K2 beads (K: $5.6 \mathrm{wt} \%)$ found in Botswana (Koleini et al.

$112016 b)$ although it is not unusual for the IP series.

12 The potassium content of more than $6 \mathrm{wt} \%$ have been reported in some of the IP beads, one

13 large black cylindrical bead (9.1 wt $\%)$ and a large round black bead (15.82 wt\%-potash glass)

14 from Mapungubwe (Prinsloo and Colomban 2008), one $\mathrm{K} 2$ Garden Roller $\left(\mathrm{K}_{2} \mathrm{O}: 8.31\right.$ wt\%

$15 \mathrm{~K}: 6.9 \mathrm{wt} \%)$, a Khami-IP bead $\left(\mathrm{K}_{2} \mathrm{O}: 9.2 \mathrm{wt} \% \cong \mathrm{K}: 7.6 \mathrm{wt} \%\right)$ (Robertshaw et al. 2010) and a recycled pale green bead found in Botswana (15 wt\%-potash glass) (Koleini et al. 2016b). The potassium content of Mutamba corroded beads $(\mathrm{Lb} 1,2)$ is too low $(<15 \mathrm{wt} \%)$ to be typical potash glass, and probably the elevated amount is caused by the use of mineral soda with a higher potassium content. An additional reason could be that the precipitation of lixiviated potassium and/or of potassium ions originated from burial soil at the corroded surface, as has been reported for some of the corroded beads (Dussubieux et al. 2009).

The precipitation of secondary corrosion products looks stronger because the beads with high potassium content (Lb1, Lb2) are corroded on the surface layer as Raman spectroscopy shows. In corroded beads, the peak maxima in the stretching envelope appears in a lower wavenumber $\left(988 \mathrm{~cm}^{-1}\right)$. The downward shift of the peak is due to lixiviation of alkali ions from $\mathrm{SiO}_{4}$ networks and the substitution of their positions by protons $\left(\mathrm{H}^{+}\right)$in acidic conditions. (Tournié et al. 2008) (Fig. 4a-2). XRF measurements also show a rise in the amount of silicon as a result of corrosion (Table 1). Un-corroded beads show typical Raman spectra of K2-IP beads (Fig. 4a-1), as previously reported (Koleini et al. 2016b; Prinsloo et al. 2012). Copper (0.6-0.9 wt $\%)$ is the only colouring element detected that forms a turquoise blue colour in the beads (Table 2). 
2 EC-IP beads in this assemblage are tubular and cylindrical with an opaque brownish-red and 3 black colours. The first red and black beads are attributed to the EC-IP series (Wood, 2011).

4 XRF results show that the beads have very close composition to K2 beads in main glass 5 elements as well as minor and trace elements such as titanium, uranium and zirconium (Fig.

65 a, Table 1). The only difference in composition is due to elements used as colorants such as 7 a high amount of $\mathrm{Fe}$ that also acts as a reducing agent for precipitation of cuprite or metallic copper in EC-IP brownish-red beads. This was also reported in Robertshaw et al. (2010). Iron, in the form of $\mathrm{Fe}^{3+}$ ions, also acts as a yellow colorant which, together with $\mathrm{Cu}$, forms a blue-green colour in IP beads. Black Indo-Pacific beads only appeared during the late occupation of K2 site with the settlement shift towards Mapungubwe during the first quarter of the thirteenth century (Wood, 2011).

Raman spectroscopy on brownish-red EC-IP bead (R1) failed, probably due to the huge absorption of light by metal nanoparticles in the glass matrix. The spectrum of the black bead (B3) with a constant peak at $412 \mathrm{~cm}^{-1}$ (Fig. 4b-1), the typical signature of Fe-S amber chromophore, is close to other recorded spectra of black IP beads from Botswana (see Koleini et al. 2016b) and black beads found in Sri Lanka and India (Prinsloo and Colomban, 2008). Fe-S chromophore, was also recorded in the black Mapungubwe oblate (B5) (Fig. 4b2). In this spectrum, the Fe-S chromophore resonance signature is shifted towards a lower wavenumber $\left(362 \mathrm{~cm}^{-1}\right)$ due to the use of a $633 \mathrm{~nm}$ laser line for spectroscopy (Table 2). However, the intensity and exact position of the Fe-S chromophore Raman resonance signature are sensitive to the laser line wavelength and show obvious fluctuations (Prinsloo and Colomban, 2008).

\subsection{Mapungubwe oblates (1240-1300 AD)}

The Mapungubwe oblates in this assemblage are opaque black and brownish-red as well as opaque-translucent turquoise-blue, green, yellow and orange (Fig. 2). Some of the beads are highly corroded with brownish-red spots or a pale golden corrosion crust on the surface. The beads in this series are generally made of a high alumina (mean $\mathrm{Al}_{2} \mathrm{O}_{3}: 7.67 \pm 1.48 \mathrm{wt} \% \cong$ mean $\mathrm{Al}: 4.1 \mathrm{wt} \%$ ) and low lime (mean $\mathrm{CaO} 6.66 \pm 1.78 \mathrm{wt} \% \cong$ mean $\mathrm{Ca}: 4.8 \mathrm{wt} \%$ ) plant ash glass (Davison, 1972; Robertshaw et al. 2010). XRF measurements show a composition with 
$16.16 \mathrm{wt} \%$ ). Magnesium and potassium concentration range from 1.49 to $2.91 \mathrm{wt} \%$ and 2.39 to

$23.36 \mathrm{wt} \%$ respectively in the less corroded beads (Table 1; Mapungubwe oblate).

3 In the beads examined, $\mathrm{Mg}$ was leached out in corroded beads and developed a composition

4 with a higher aluminium (mean $\mathrm{Al}$ : $9.57 \pm 0.52 \mathrm{wt} \%$ ) and magnesium lower than the detection

5 limit compared with un-corroded Mapungubwe oblate beads (Fig. 5a, Table 1: Bg-Cor).

6 Calcium content (mean Ca: $4.13 \pm 0.48 \mathrm{wt} \%$ ) almost remained constant in the corroded beads

7 as seen in Fig. 5a. Calcium (lime) mainly originated from the soda-ash, and acts as a

8 stabilizer in the glass structure by reducing its solubility in water (Freestone, 2006).

9 The lixiviation changed the composition of Mapungubwe oblates so that the concentration of

10 the main detectable glass elements $(\mathrm{Mg}, \mathrm{K}, \mathrm{Al}, \mathrm{Ca})$ after corrosion becomes similar to

11 Khami-IP beads (Fig. 5b) (Koleini et al. 2017). In this case, the concentration of trace

12 elements $(\mathrm{Zr}, \mathrm{U})$ will offer a way to discriminate between the two series of Khami-IP and

13 Mapungubwe. The latter contains zirconium (mean Zr: $49 \pm 29 \mathrm{ppm}$ ) and uranium with an amount lower than the detection limit of pXRF when compared to Khami-IP beads with a high zirconium (mean $\mathrm{Zr}: 132 \pm 52 \mathrm{ppm}$ ) and uranium (mean U: $58 \pm 22 \mathrm{ppm}$ ) concentrations (Koleini et al.2017). The same trend has been noted for zirconium and uranium content of the abovementioned series by using the LA-ICP-MS analysing technique (Robertshaw et al. 2010), although it shows higher concentrations of each element. The zirconium content of the glass is related to the source of sand which is different in the production of the two mentioned series.

Raman spectra provide the typical pattern of Mapungubwe oblates with maximum peak at $579 \mathrm{~cm}^{-1}$ in bending and three stretching components $\left(955,993,1090 \mathrm{~cm}^{-1}\right)$ with gradual increases in intensity toward higher wavenumbers (Fig. 4a-3) (Koleini et al. 2016b; Prinsloo and Colomban, 2008).

The detected pigments, colouring agents and opacifier are the same as those recorded in the oblates recovered at Mapungubwe Hill (Prinsloo and Colomban, 2008). A summary of Raman signature of pigments and opacifiers is provided in Table 2. Lead tin yellow type (II) was found in the yellow, orange, and green beads, plus copper as the colorant of the blue matrix for the later (Fig. 4b-4). In the orange bead, red lead is also present (Fig. 4b-5) in combination with zinc, identified with XRF (Table 1).

Tin oxide $\left(\mathrm{SnO}_{2}\right)$ works as an opacifier in copper- coloured blue-green and green beads (Fig. 4b-6, Table 2). The Raman spectroscopy found no traces of lead tin yellow type (II) in the 
1 blue-green beads ( $\mathrm{Bg} 3$ and $\mathrm{Bg} 5)$, although a low amount of $\mathrm{Pb}(0.3-1.8 \mathrm{wt} \%)$ is present in the compositions of these beads. Manganese (mean $0.6 \mathrm{wt} \%$ ) was detected in yellow and orange

3 beads and it could have been used for eliminating the colour effect of iron, hence

4 decolourising the glass.
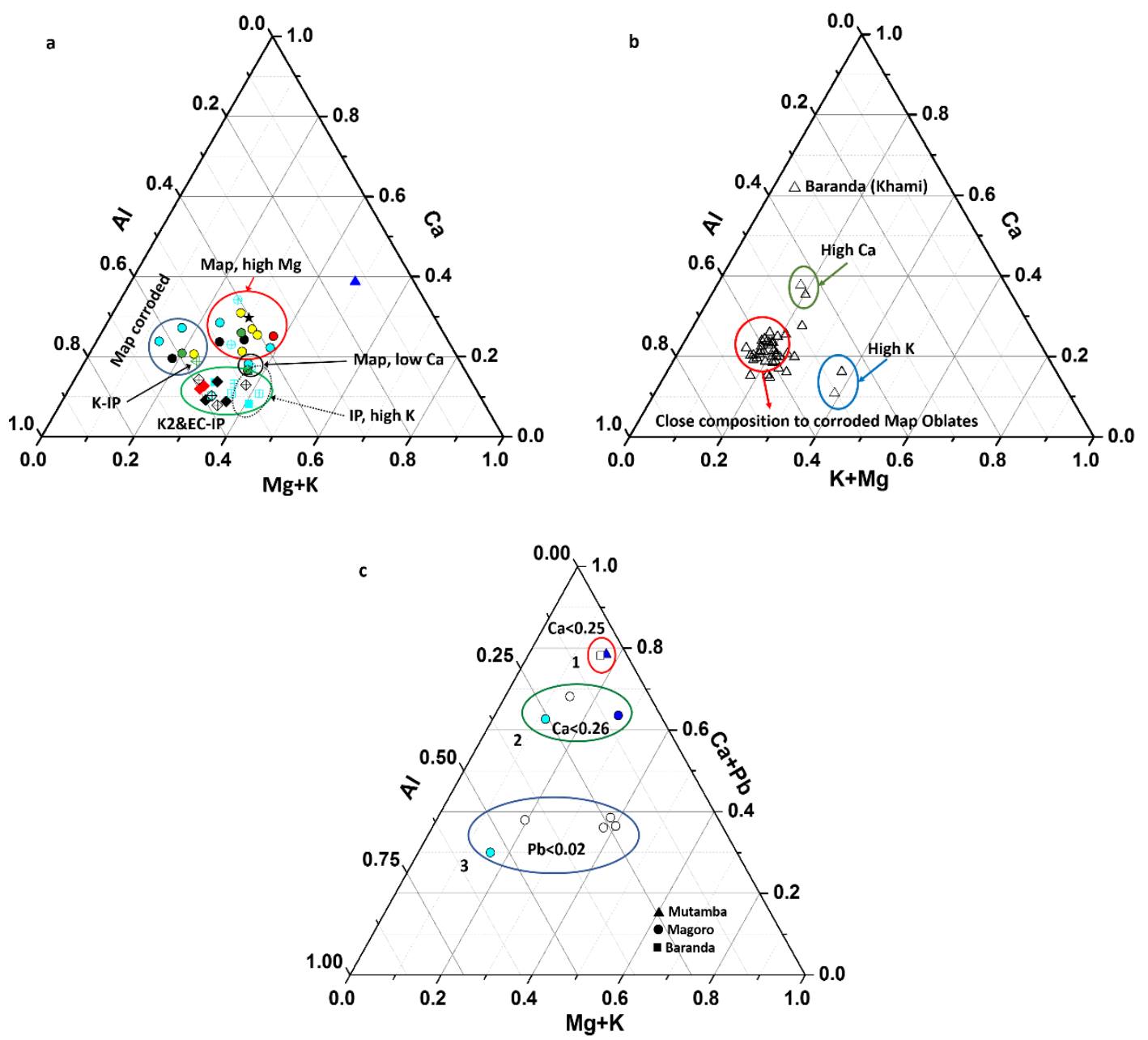

Figure 5: a) A comparison of $\mathrm{K}+\mathrm{Mg}, \mathrm{Ca}$ and $\mathrm{Al}$ elemental content of the bead series recovered at Mutamba site and Basinghal Farm. $\odot$ Mapungubwe Oblate, $\square$ K2-IP, $\diamond$ EC-IP, $\triangleleft$ K-IP and $\triangle$ European. $\star$ shows MutambaB1. Plain colour fill shows the colour of Mutamba beads while + is the indicator of beads found on Basinghal Farm and their colour; b) Concentration of $\mathrm{Ca}, \mathrm{K}+\mathrm{Mg}$ and $\mathrm{Al}$ in Khami-IP beads from Baranda Farm; c). A comparison between $\mathrm{Al}, \mathrm{Mg}+\mathrm{K}$ and $\mathrm{Pb}+\mathrm{Ca}$ of European beads (soda/lime) opacified with calcium antimonite from Mutamba, Magoro Hill (South Africa) and Baranda Farm (Zimbabwe). Group 1: very low aluminium glass with high lead content. Group 2: The same Calcium content as (group 1) with higher aluminium and lower lead. Group 3: High calcium glass with lead as contaminant $(\mathrm{Pb}<0.2 \mathrm{wt} \%)$. Colour fills show colour of the beads. 


\subsection{European beads}

2 Two of the beads (B1 and Db1) were classified, based on morphology, as of European origin.

3 B1 has a well-shaped tubular form with round ends and a very shiny black appearance with

4 no corrosion and defect on the surface. This makes it quite different from EC-IP and

5 Mapungubwe black beads. Despite this, XRF shows that B1 is quite similar to Mapungubwe

6 oblates in its composition (Fig. 5a). The bead was coloured with Fe-S chromophore (Fig. 4b-

7 3) and was categorized into the soda/lime group as a Mapungubwe oblate (Fig. 3). The bead

8 also contains trace elements concentration $(\mathrm{Zr}, \mathrm{U})$ very similar to the Mapungubwe oblates

9 (Table 1).

$10 \mathrm{Db} 1$ is a soda/lime glass (Fig. 3) that opacified with calcium antimoniate (Fig. 4b-7). The 11 bead contains very low aluminium $(0.7 \mathrm{wt} \%)$ and lead, of about $10.6 \mathrm{wt} \%$ (Table 1). The 12 composition of glass matrix is very close to some of the opacified beads with calcium 13 antimonite $\left(\mathrm{CaSb}_{2} \mathrm{O}_{7}\right)$ from Magoro Hill (South Africa) (Fig. 5c, group 2) and completely 14 matched with a white early European traded bead found at sixteenth -seventeen century AD 15 site of Baranda -in northern Zimbabwe (Fig. 5c, group 1). All these beads are a low 16 aluminium soda/lime glass that can be differentiated based on their aluminium and lead 17 content. The concentration of lead in these beads (5-13 wt\%) shows it was deliberately added 18 to make the melting of metals ( $\mathrm{Cu}, \mathrm{Co})$ and antimoniate easier (Francis, 1990). Calcium 19 antimonite was in use as an opacifier since antiquity, but was replaced by tin oxide in the 20 Mediterranean world with the spread of the Islamic pottery and from the late seventeenth till nineteenth centuries was the prominent opacifier once again (Ricciardi et al. 2009).

22 Therefore, the bead dates from the late seventeenth to the nineteenth century.

23 Minor contaminants found together with cobalt are silver, manganese and nickel. This was 24 the same as the cobalt used in colouring of the hexagonal and annular (Dutch or Dogon 25 doughnuts) European beads from Magoro Hill (Koleini et al. 2016a). The other characteristic of cobalt used in the abovementioned European beads is their low Co/As ratio $(<0.3)$ and low iron content $(<1 \mathrm{wt} \%)$. The Mutamba dark blue bead shows a higher arsenic content than the Persian and European cobalt sources. The arsenic content was high enough to be detected by XRF with the presence of high lead in the composition. A part of arsenic may come along with lead into the glass matrix (Gratuze et al.1992) therefore, we did not consider $\mathrm{Co} / \mathrm{As}$ ratio for finding the cobalt sources. 
1 The association of Db1 cobalt with a low iron content, silver and nickel brings Db1 closer to

2 European sources. The source of cobalt could be Erzgebirge Mountain in Saxony where the

3 pigment were produced from sulpho-arseniates as minerals with silver content from twelfth century (Colomban, 2013; Gratuze et al.1992, 1996; Zuchchiatti et al. 2006).

5 The single European bead (Db1) is in contrast with the rest of the assemblage - both in terms

6 of morphology and chemical composition. It is most likely associated with the small postseventeenth century settlement associated with Letaba ceramics, located adjacent to Mutamba (Antonites, 2012; Loubser, 1988) and can therefore be regarded as intrusive to the Middle

9 Iron Age deposits.

\section{Conclusion}

The Mutamba beads are mostly covered with a surface layer of corrosion that makes discrimination of series with a common shape, such as Mapungubwe and EC-IP cylinders or Mapungubwe and Khami oblates challenging. G3 and Bg5 are good examples in the Mutamba assemblage. In a case like this, $\mathrm{pXRF}$ and Raman spectroscopy are powerful techniques in distinguishing the correct bead series on corroded specimens.

The corroded K2-IP beads as analysed through Raman showed surprisingly high levels of potassium. This could be due to the precipitation of potassium minerals on the bead surface through the reaction of dissolved potassium and soluble salts in the burial environment. Since IP beads with high potassium content were also reported from other archaeological sites, it is recommended that elemental mapping (SEM-EDS) is performed on the un-corroded cross sections of these beads to reveal the pristine glass composition for more accurate conclusions.

The corroded Mapungubwe oblates (plant-ash glass) lost their magnesium. As a result, their composition is very close to the pristine Khami-IP series (mineral-soda glass). In such conditions, these two series can be discriminated by the concentration of trace elements of zirconium and uranium which are higher in IP series. Tin oxide is another discriminating factor that was used as the opacifier in Mapungubwe blue-green and green beads while Khami-IP beads have no sign of it in the composition. Khami red and green beads usually contain a higher concentration of iron compared to Mapungubwe oblates of the same colour. The only European bead in the assemblage is easily distinguished from the earlier series by the morphology and in the composition. The bead contains very low aluminium and calcium 
1 cobalt in this European bead. The rarity of European beads at the site may imply the bead was arrived there at a later date. The bead is one of the early European trading beads resembling those found at the sixteenth-seventeenth century AD Baranda (Massapa) in Zimbabwe and dates to the late seventeenth century. It is most likely associated with the occupation of a recent site adjacent to Mutamba whose ceramics suggest a post seventeenth century date. It does however serve as a reminder of how easily small objects like single beads are affected by processes of bioturbation. Regardless, the appearance of black and red EC-IP beads along with Mapungubwe and K2 series confirms the occupation of the site spans from the late $\mathrm{K} 2$ times to the Mapungubwe period.

Chemical classification by means of Raman and XRF techniques provides a line of evidence that complements radiometric and relative dating (e.g. through ceramics) of archaeological sites in southern Africa. In the case of Mutamba, the presence of beads from the K2-IP beads (980-1200) clearly indicates the extent of trade networks preceding political dominance of the Mapungubwe polity during the thirteenth century. While the emergence of Mapungubwe as a regional political force is associated with the expansion of trade over an increasingly wider area in southern Africa, it has been suggested that the initial distribution of glass beads was restricted to "higher levels of political leadership" (Calabrese 2007: 221; also see Hall 1990: 89). However, the Mutamba data suggest that many of the smaller communities outside the Shashe-Limpopo Confluence Area articulated with long distance trade networks prior to the consolidation of power in the area Confluence. Therefore, while centres like Mapungubwe are often cast as the catalysts for long distance trade, the Mutamba data serve as an important reminder that social and political power emerged from a landscape in which communities were already tied to complex networks of social and economic interaction.

\section{Acknowledgements}

The authors would like to thank Noemie Fischbach (University of Sorbonne) for conducting Raman spectroscopy on the beads, Marilee Wood for providing complementary samples and the property owners Hector and Hazel Kincaid-Smith for access to the site of Mutamba.

29 Financial support came from National Research Foundation (NRF) [Grant Number UID

30 81857]; the National Science Foundation [Grant Number 1058306] and the MacMillan

31 Centre for International and Area Studies at Yale as well as the Yale University Council for 32 Archaeological Studies. 


\section{References}

2 Abraham, S.A., 2016, Glass beads and glass production in ealy south India: Contextualizing 3 Indo-Pacific bead manufacture, Archaeol. Res. Asia 6, 4-15.

4 Antonites, A., 2012. Political and Economic Interactions in the Hinterland of the

5 Mapungubwe Polity, 10th-13th Century South Africa. PhD Dissertation, Yale University.

6 Antonites, A., 2014. Glass beads from Mutamba: patterns of consumption in thirteenth-

7 century southern Africa. Azania: Archaeol. Res. in Afr. 49 (3), 411-28.

8 Beaujard, Ph., 2009. Un seul système-monde avant le 16e siècle? L'océan Indien au cœur de

9 l'intégration de l'hémisphère afro-eurasien, in Ph. Beaujard, L. Berger et P. Norel (dir.) Histoire

10 globale, mondialisations et capitalisme: 82-148. Paris: La Découverte-Recherches.

11 Beaujard, Ph., 2012. Les mondes de l'océan Indien. Vol. 1, De la formation de l'Etat au premier 12 système monde afro-eurasien. Vol. 2, L'océan Indien, au cour des globalisations de l'Ancien Monde 13 (7e-15e siècles). Armand Colin, Paris.

14 Brand, N. W., Brand, C. J. 2014. Performance comparison of portable XRF instruments. Geochem. 15 Explor. Environ. Anal. DOI: 10.1144/geochem2012-172

16 Calabrese, J.A., 2007. The Emergence of Social and Political Complexity in the Shashi-Limpopo 17 Valley of Southern Africa, AD 900 to 1300: Ethnicity, Class, and Polity. Archaeopress, Oxford.

18 Colomban, Ph., 2003. Polymerisation degree and Raman identification of ancient glasses used for 19 jewellery, ceramics enamels and mosaics. J. Non-Cryst. Solids. 323, 180-187.

20 Colomban, Ph., March, G., Mazerolles, L., Karmous, T., Ayed, N., Ennabli, A., Slim. H., 2003.

21 Raman identification of materials used for jewellery and mosaics in Ifriqiya. J. Raman Spectrosc. 34 22 (3), 205-213.

23 Colomban, $\mathrm{Ph} ., 2013$. Rocks as blue (green and black) pigments/dyes of glazed pottery and enamelled 24 glass artefacts - A review. Eur. J. Mineral. 25 (5), 863-879.

25 Davison, C.C., 1972. Glass Beads in African Archaeology: Results from neutron activation analysis 26 supplemented by results of X-Ray fluorescence analysis. PhD Dissertation, University of California, 27 Berkeley.

28 Denbow, J., Klehm, C., Dussubieux. L., 2015. The glass beads of Kaitshaa and early Indian Ocean 29 trade into the Far Interior of southern Africa. Antiq. 89 (344), 361-377.

30 Dussubieux, L., Gratuze, B., Blet-Lemarquand, M., 2010. Mineral soda alumina glass: occurence and 31 meaning. J. Archaeol. Sci. 37, 1646-1655.

32 Dussubieux, L., Robertshaw, P., Glascock. M.D., 2009. LA-ICP-MS analysis of African glass beads: 33 Laboratory inter-comparison with an emphasis on the impact of corrosion on data interpretation. Int. 34 J. Mass Spectrom. 284, 152-161.

35 Fouché, L., (ed.) 1937. Mapungubwe, Ancient Bantu Civilization on the Limpopo. Vol. 1. Cambridge 36 University Press, Cambridge.

37 Francis, JR., P., 1990. Glass Beads in Asia: Part I. Introduction. Asian Perspect. 28 (1), 1-21. 
1 Francis, JR., P., 2002. Asia's Maritime Bead Trade, 300BC to the Present, University of Hawaii

2 Press.

3 Freestone, I.C., 2006. Glass production in Late Antiquity and the Early Islamic period: a geochemical 4 perspective, in: Maggetti, M., Messiga, B., (Eds.), Geomaterials in Cult. Hérit. The Geological 5 Society, London, pp. 201-216.

6 Gratuze, B., Soulier, I., Barrandon, J.N., Foy. D., 1992. De l'origine du cobalt dans les verres. Rev.

7 d'Archéomètrie 16, 97-108.

8 Gratuze, B., Soulier, I., Blet, M., Vallauri, L., 1996. De l'origine du cobalt: du verre à la céramique.

9 Rev. d'Archéomètrie 20, 77-94.

10 Huffman, T.N., 2000. Mapungubwe and the Origins of the Zimbabwe Culture. Goodwin Ser. 8, 141129.

Huffman, T.N., 2007. Handbook to the Iron Age: The Archaeology of Pre-Colonial Farming Societies in Southern Africa. University of KwaZulu-Natal Press, Scottsville.

Koleini, F., Pikirayi, I., Colomban, Ph., 2017. Revisiting Baranda: A multi-analytical approach in the classification of sixteenth/seventeenth-century glass beads from Northern Zimbabwe. Antiq.

doi:10.15184/aqy.2017.46

Koleini, F., Prinsloo, L.C., Biemond, W.M., Colomban, Ph., Nego, A., Boeyens, J., van der Ryst, M., van Brakel, K., 2016a. Unravelling the glass trade bead sequence from Magoro Hill, South Africa: separating pre-17th-century Asian imports from later European counterparts. Herit. Sci. 4(4). DOI 10.1186/s40494-016-0113-2

Koleini, F., Prinsloo, L.C., Biemond, W.M., Colomban, Ph., Nego, A., Boeyens, J., van der Ryst, M., 2016b. Towards refining the classification of glass trade beads imported into southern Africa from the 8 th to the 16th century AD. J. Cult. Herit. 19, 435-444.

Neri, E., Morvan, C., Colomban, Ph., Guerra, M.P., Prigent, V., 2016, Late Roman and Byzantine Mosaic opaque 'Glass-ceramics' Tessarae (5th -9th century). Ceram. Int. 42(16), 18859-18869.

Prinsloo, L.C., Colomban, Ph., 2008. A Raman spectroscopic study of the Mapungubwe oblates: glass trade beads excavated at an Iron Age archaeological site in South Africa. J. Raman Spectrosc. 39, 7990.

Prinsloo, L.C., Tournié, A., Colomban, Ph., 2011. A Raman spectroscopic study of glass trade beads excavated at Mapungubwe hill and K2, two archaeological sites in southern Africa, raises questions about the last occupation date of the hill. J. Archaeol. Sci. 38, 3264-3277. study of Roman age mosaic glass tesserae by means of Raman spectroscopy. J. Archaeol. Sci. 36, 2551-2559. Oman: a multidisciplinary approach, Proc. Sem. Arab. Stud., Suppl. 44, 287-298.

39 Simsek, G., Casadio, F., Colomban, Ph., Faber, K., Bellot-Gurlet, L., Zelleke, G., Milande, V., 40 Moinet, E., 2014, On-site identification of earlier Meissen Böttger red stonewares using portable 41 XRF: 1, body analysis, J. Am. Cer. Soc. 97(9), 2745-2754. 
Schofield, J. F., 1938. A Preliminary Study of the Prehistoric Beads of the Northern Transvaal and Natal. Trans. Royal Soc. S. Afr. 26, 341-71.

3 Tournié, A., Ricciardi, P., Colomban, Ph., 2008. Glass corrosion mechanisms: A multiscale analysis.

$4 \quad$ Solid State Ion. 179(38), 2142-2154.

Tournié, A., Prinsloo, L.C., Paris C, Colomban, Ph Smith B, 2011, The first in situ Raman spectroscopic study of San rock art in South Africa: procedures and preliminary results, J. Raman Spectrosc. 42, 399-406.

Tournié, A., Prinsloo, L.C., Colomban, Ph., 2012. Raman classification of the glass beads excavated on Mapungubwe hill and K2, two archaeological sites in South Africa. J. Raman Spectrosc. 43(4),

$12532-542$.

13 Zuchchiatti, A., Bouquillon, A., Katona, I., D'Alessandro, A., 2006. The 'Della robbia blue': A case study for the use of cobalt pigments in ceramic during the Italian Renaissance. Archaeom. 48, 131.

Wood, M., 2000. Making connections: relationships between international trade and glass beads from the Shashe-Limpopo Area. Goodwin Ser. 8, 78-90.

Wood, M., 2011. A glass bead sequence for Southern Africa from the 8th to the 16th century AD. $J$.

18 Afr. Archaeolog. 9 (1), 67-84.

Wood, M., Dussubieux, L., Robertshaw, P., 2012. The glass of Chibuene, Mozambique: new insights into early Indian Ocean trade. S. Afr. Archaeol. Bull. 67(195), 59-74. 
Table 1: Elemental composition of glass beads (mean concentration of elements in wt $\%$ or ppm*) with considering bead series, colour and numbers of analysed beads (n). ST.Dev has been reported for the main glass elements.

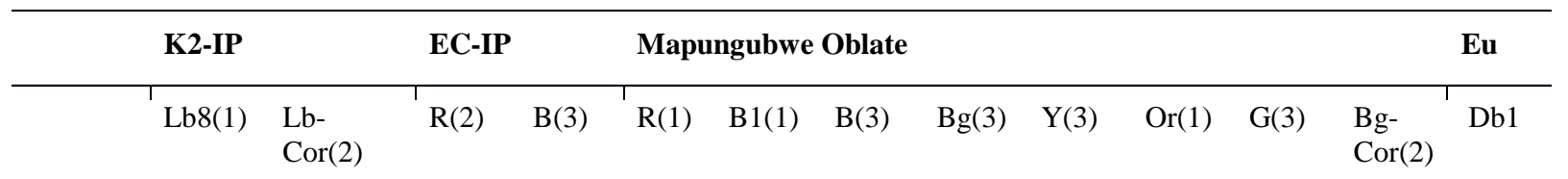

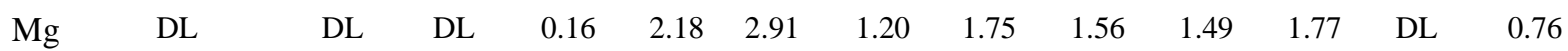

\begin{tabular}{|c|c|c|c|c|c|c|c|c|c|c|c|c|c|}
\hline ST.Dev & & - & & 0.28 & & & 0.60 & 0.63 & 1.11 & & 0.82 & & \\
\hline $\mathrm{Al}$ & 8.28 & 9.88 & 7.63 & 7.29 & 5.47 & 8.35 & 7.22 & 6.38 & 7.19 & 6.30 & 7.20 & 9.57 & 0.73 \\
\hline ST.Dev & & 2.17 & 0.48 & 0.45 & & & 0.31 & 1.31 & 1.23 & & 1.44 & 0.52 & \\
\hline $\mathrm{Si}$ & 49.24 & 53.74 & 41.69 & 42.95 & $\begin{array}{l}46.1 \\
0\end{array}$ & 55.87 & 45.80 & 41.42 & 42.31 & 36.40 & 43.49 & 46.46 & 32.98 \\
\hline ST.Dev & & 3.31 & 1.68 & 3.47 & & & 1.12 & 3.89 & 4.49 & & 3.20 & 4.17 & \\
\hline $\mathrm{K}$ & 4.55 & 7.82 & 3.69 & 4.04 & 3.36 & 3.32 & 2.52 & 2.87 & 3.15 & 3.01 & 2.39 & 2.45 & 2.03 \\
\hline ST.Dev & & 1.86 & 0.34 & 0.48 & & & 0.85 & 0.45 & 0.39 & & 0.50 & 0.43 & \\
\hline $\mathrm{Ca}$ & 2.02 & 2.36 & 1.59 & 1.37 & 3.69 & 6.16 & 3.21 & 3.37 & 3.84 & 2.92 & 3.01 & 4.13 & 2.23 \\
\hline ST.Dev & & 0.77 & 0.19 & 0.41 & & & 0.76 & 1.25 & 0.80 & & 0.43 & 0.48 & \\
\hline S & 0.34 & 0.51 & 0.20 & 0.44 & 0.25 & 0.86 & 0.26 & 0.59 & 1.81 & 2.84 & 1.09 & 0.54 & 3.70 \\
\hline $\mathrm{Cl}$ & 1.12 & 1.63 & 1.29 & 1.55 & 1.08 & 2.83 & 0.49 & 1.10 & 0.10 & 0.83 & 0.72 & 0.39 & 1.42 \\
\hline $\mathrm{Ti}$ & 0.20 & 0.20 & 0.23 & 0.18 & 0.11 & 0.19 & 0.16 & 0.12 & 0.12 & 0.10 & 0.13 & 0.14 & $427 *$ \\
\hline $\mathrm{V}$ & $122^{*}$ & $236^{*}$ & $219 *$ & $112^{*}$ & $61 *$ & $53 *$ & $58 *$ & $44^{*}$ & $51 *$ & DL & $59 *$ & DL & DL \\
\hline $\mathrm{Mn}$ & $204^{*}$ & $72 *$ & $204 *$ & $106 *$ & $286^{*}$ & $286^{*}$ & $355^{*}$ & $212 *$ & $\underline{0.68}$ & $\underline{0.63}$ & $419 *$ & $265^{*}$ & 0.22 \\
\hline $\mathrm{Fe}$ & 1.22 & 1.46 & $\underline{3.43}$ & 1.91 & $\underline{2.65}$ & 1.34 & 1.45 & 1.14 & 1.21 & 1.04 & 1.24 & 1.24 & 0.53 \\
\hline $\mathrm{Co}$ & $\mathrm{DL}$ & DL & $\mathrm{DL}$ & DL & DL & DL & DL & DL & DL & DL & DL & DL & $\underline{766^{*}}$ \\
\hline $\mathrm{Ni}$ & $\mathrm{DL}$ & DL & DL & DL & DL & $\mathrm{DL}$ & DL & DL & $26 *$ & DL & DL & DL & $558 *$ \\
\hline $\mathrm{Cu}$ & $\underline{0.64}$ & $\underline{0.76}$ & $\underline{0.28}$ & $148^{*}$ & $\underline{1.23}$ & $102 *$ & $144^{*}$ & $\underline{0.84}$ & $245^{*}$ & $81 *$ & $\underline{1.08}$ & 1.02 & 0.13 \\
\hline $\mathrm{Zn}$ & $616^{*}$ & $24 *$ & DL & DL & $191 *$ & $63^{*}$ & $35 *$ & $56^{*}$ & DL & $\underline{0.38}$ & $25^{*}$ & $33 *$ & $135^{*}$ \\
\hline As & $150^{*}$ & $80 *$ & $24 *$ & DL & $353^{*}$ & $20^{*}$ & DL & DL & DL & $564^{*}$ & DL & DL & 1.79 \\
\hline $\mathrm{Rb}$ & $85^{*}$ & $99 *$ & $69 *$ & $88^{*}$ & $24 *$ & $23^{*}$ & $23 *$ & $26^{*}$ & $36^{*}$ & $27 *$ & $33 *$ & $31^{*}$ & $19 *$ \\
\hline $\mathrm{Zr}$ & $464^{*}$ & $348^{*}$ & $594^{*}$ & $592 *$ & $62 *$ & $82 *$ & $81 *$ & $64 *$ & $23 *$ & DL & $38 *$ & $55^{*}$ & DL \\
\hline $\mathrm{Ag}$ & $\mathrm{DL}$ & DL & $27 *$ & DL & DL & $\mathrm{DL}$ & $\mathrm{DL}$ & $68 *$ & $72 *$ & $136 *$ & $59 *$ & DL & $364 *$ \\
\hline $\mathrm{Sn}$ & $162 *$ & $94 *$ & $\mathrm{DL}$ & DL & $139^{*}$ & $25^{*}$ & $71 *$ & $\underline{1.00}$ & $\underline{0.67}$ & $\underline{1.28}$ & $\underline{0.92}$ & $\underline{1.08}$ & $405^{*}$ \\
\hline $\mathrm{Sb}$ & $32 *$ & $27 *$ & 0.001 & DL & $43^{*}$ & DL & DL & $28 *$ & $50 *$ & DL & $45^{*}$ & DL & $\underline{3.49}$ \\
\hline $\mathrm{Ba}$ & $202^{*}$ & $209^{*}$ & $316^{*}$ & $278^{*}$ & $178^{*}$ & $113^{*}$ & $162 *$ & $275^{*}$ & $372 *$ & $522 *$ & $332 *$ & $251 *$ & $512 *$ \\
\hline $\mathrm{Pb}$ & $949^{*}$ & $486^{*}$ & 0.003 & $143^{*}$ & $417^{*}$ & $77 *$ & $82 *$ & $\underline{1.09}$ & $\underline{4.42}$ & $\underline{7.67}$ & $\underline{2.83}$ & $\underline{1.43}$ & 10.63 \\
\hline $\mathrm{U}$ & $15^{*}$ & $49 *$ & $59 *$ & $35^{*}$ & DL & DL & DL & DL & DL & $\mathrm{DL}$ & DL & DL & DL \\
\hline
\end{tabular}


33.7

Note: Underline shows the elements was used as colorant or presents in the composition of a pigment. Lb: Light blue, R: Red, B: Black, Bg: Blue-green, Or: Orange, G: Green, Db: Dark blue, Cor: Corroded, DL: below the detection limits. (n): number of analysed beads, ST.Dev: standard deviation

1

2

3

4

5

6

7

8

9

10

11

12

13

14

15

16

17

18

19

20

21

22

23 
Table 2: detected colorants (XRF) and Raman signature of pigments and attributed series

\begin{tabular}{|c|c|c|c|c|}
\hline & Chromophore/phase or pigment & Raman signature & Bead series & Sample \\
\hline Blue green & $\mathrm{Cu}^{2+}, \mathrm{Pb}, \mathrm{Sn} / \mathrm{SnO}_{2}$ & $-\quad / 635,775$ & Map Oblate & $\mathrm{Bg} 3, \mathrm{Bg} 5$ \\
\hline Light blue & $\mathrm{Cu}^{2+} /-$ & - & K2-IP & $\mathrm{Lb} 1, \mathrm{Lb} 2, \mathrm{Lb} 8$ \\
\hline Yellow & Mn/Lead tin yellow(II) & $-/ 135,329,450$ & Map Oblate & $\mathrm{Y} 1, \mathrm{Y} 3, \mathrm{Y} 4$ \\
\hline Orange & Mn, Zn/Lead tin yellow(II) + red lead & - / 73,110,136,280,335, 435 & Map Oblate & Or2 \\
\hline Green & $\mathrm{Cu}^{2+} / \mathrm{SnO}_{2}+$ Lead tin yellow(II) & $-/ 635,775 / 128,317,442$ & Map Oblate & G1, G3 \\
\hline Red & $\mathrm{Cu}, \mathrm{Fe} /-$ & - & $\begin{array}{l}\text { EC-IP } \\
\text { Map Oblate }\end{array}$ & $\mathrm{R} 1, \mathrm{R} 2$ \\
\hline Black & $-/ \mathrm{Fe}-\mathrm{S}$ & $-/ 300,362,412^{\mathrm{a}}$ & Map Oblate & B5 \\
\hline Black & $-/ \mathrm{Fe}-\mathrm{S}$ & $-/ 355,412$ & Map Oblate & B1 \\
\hline Black & $-/ \mathrm{Fe}-\mathrm{S}$ & $-/ 412$ & EC-IP & B3 \\
\hline Dark blue & $\mathrm{Co} / \mathrm{Ca}$-antimonite & $-/ 480,633$ & Europe & Db1 \\
\hline
\end{tabular}

${ }^{a}$ measured with $632 \mathrm{~nm}$ laser line 